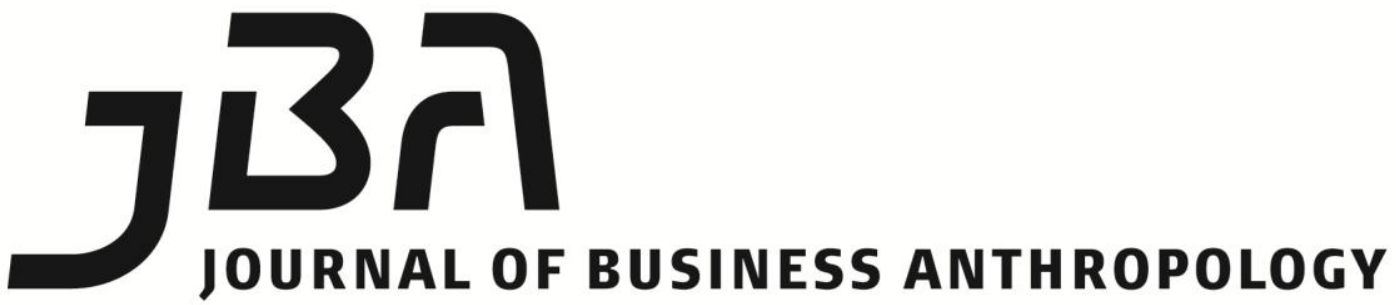

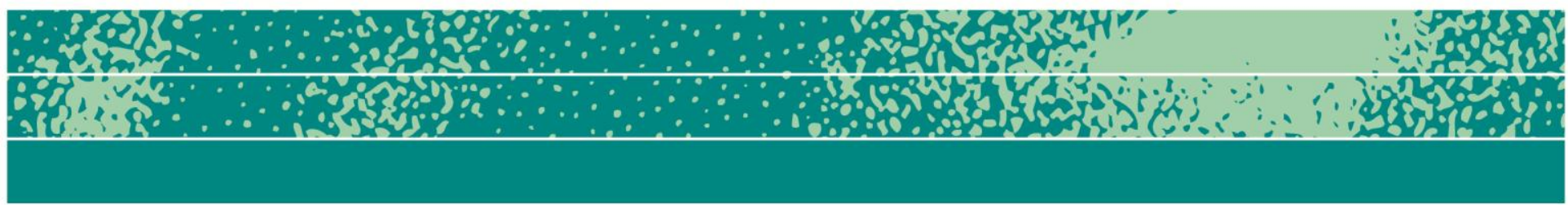

\section{The Anthropology of Chinese Capitalism in Southeast Asia: From Culture to Institution?}

\author{
Michiel Verver and Heidi Dahles
}

\begin{abstract}
This article outlines the contours of the scholarly debate on 'Chinese capitalism' in Southeast Asia. This multidisciplinary domain is businessand entrepreneurship-oriented, and concerns the ethnic Chinese who have migrated from Southern China to Southeast Asia and have come to play a dominant role in the region's economies over the centuries. The debate revolves around the competing assumptions that ethnic Chinese business success in Southeast Asia relies either on ethnic affiliation and shared cultural values, or on strategic deployment of resources, power relations and institutional co-optation. We distinguish four perspectives on 'Chinese capitalism', and argue that the concept of culture holds the debate hostage in the divide between essentialism and anti-essentialism. The promise of an 'anthropology of Chinese capitalism' resides in matters of perspective, therefore, rather than in the theoretical concept of culture itself. We advocate a liaison amoureuse between business anthropology and institutional theory.
\end{abstract}

Keywords: Chinese capitalism, Southeast Asia, business anthropology, culture, institutions 


\section{Introduction}

Business anthropology has been, and is being, developed primarily in Europe and the United States, but what about in other parts of the world ${ }^{1}$ Let us be blunt about it. There is no such thing as a 'business anthropology of Southeast Asia'; nor is there an economic, applied, or whatever other kind of anthropology of the region. Worse, a number of prominent scholars have observed that there is not even an 'anthropology of Southeast Asia' (Halib and Huxley 1996; King and Wilder 2003) in terms of a clearly delineated field of practice organized in a geographical area surrounded by unambiguous boundaries - physical, political, or cultural. The work of anthropologists in the region has been of a highly specialized nature - focusing on particular problems ('ethnic conflict'), a particular subject area ('rice agriculture'), single peoples ('the peoples of Borneo') or states ('the study of Thailand'). Conversely, anthropologists are prominently represented among those who identify themselves, and are identified by peers, as Southeast Asian scholars. Historically, the field of Southeast Asian Studies as a regional discipline accommodates a multitude of disciplines and subject areas that do engage the economic dimension, but rarely put business or entrepreneurship centre stage. As Halib and Huxley diagnose in their seminal Introduction to Southeast Asian Studies, this regional field of studies is dominated by Western concepts and theories 'grounded firmly in traditions that emphasize cultural interpretations of the region and processes of modernization' (1996: 6).

Culture being a prominent concern, it does not come as a surprise that the boundaries of the region have been fiercely debated among Southeast Asian scholars. The area that may be defined in terms of Southeast Asia roughly covers the south-eastern region of the continent of Asia, including the lands that lie to the south of China and to the east of India (Hill and Hitchcock 1996: 11). Whereas Southeast Asia as a 'geopolitical imagination' is to a large extent a product of US Cold War politics, in which Southeast Asia was played off against the 'Chinese threat' (Glassman 2005: 802), the region is in fact characterized by a pronounced religious, cultural and ethnic diversity that came into being long before European colonial powers encouraged and facilitated the settlement of (predominantly Chinese and Indian) migrants. For many

\footnotetext{
* Acknowledgements: The authors gratefully acknowledge the support of the Netherlands Organisation for Scientific Research (NWO) Science for Global Development department (WOTRO) through the Cambodia Research Group, as well as the constructive comments of two anonymous reviewers.
} 
centuries, there was a considerable mobility of traders and merchants, religious travellers and scholars, and adventurers and explorers, within and across the region. Colonialism enhanced these flows of human capital. A factor of great significance in these cross-regional movements are the ethnic Chinese who came to populate coastal ports, the mining areas in southern Burma, the Malay peninsula, western Borneo, and the large rice growing areas such as the mainland Southeast Asian plains and large cities (Kuhn 2008). The study of the ethnic Chinese constitutes a separate domain which partially but not completely converges with the field of Southeast Asian Studies, but which is more business- and entrepreneurship-oriented than either anthropological or regional studies of the region (cf. King and Wilder 2003: 11-12, 19-20). This domain shows a measure of coherence in that scholars seem to agree to disagree about the role of culture in ethnic Chinese business and entrepreneurship. The ensuing debate accrues to what we will label as an 'anthropology of Chinese capitalism', the contours of which this article makes an attempt at outlining here. Such a discipline has to be understood in terms of a multidisciplinary approach to economic relations embedded in the ethnically and culturally diverse economies of the region.

This article is structured as follows. First, we zoom in on the concept of culture which constitutes the very fundament on which anthropology as an academic discipline is built and which also fuels the debate about ethnic Chinese business and entrepreneurship. Second, we review academic literature on ethnic Chinese business in Southeast Asia and abstract various perspectives of 'Chinese capitalism' that differently perceive of the relationship between culture and business. Third, in the discussion section, we revisit the Chinese capitalism debate, in particular the deployment of the concept of culture, and advocate a liaison amoureuse between business anthropology and institutional theory.

\section{The Predicament of Culture}

Between the 1960s and 1990s, the highly developed and - mostly Chinese-dominated economies of East and Southeast Asia accomplished exceptionally high growth rates by pursuing an export-oriented model of economic development. Analysts outdid themselves in superlatives to capture the grandeur of this 'Asian Miracle' that changed the established international division of labour. The phrase Asian Century was coined to encapsulate the belief expressed by Asian leaders that the 21st century would be ruled by Chinese-dominated Asian economics, politics and culture. Indeed, the role of China in the region is remarkable. In terms of the sheer volume of investments, acquisitions and development aid, China has established itself as a powerful competitor and threat to Western hegemony. The often prominent role of the ethnic Chinese in economic development and, currently, as promoters of China's economic interests 
in the countries that take them in as sojourners and immigrants, has fuelled an academic debate about the factors underlying their economic importance.

As has previously been the case with social science literature on business and the economy in Southeast Asia, the debate about Chinese business in Southeast Asia is multi-disciplinary - including historians, sociologists, management scholars, social geographers and anthropologists - and focuses primarily on the relationship between culture and the economic sphere. The debate revolves around the competing assumptions that ethnic Chinese business success in Southeast Asia and beyond relies either on ethnic affiliation and shared cultural values, or on strategic deployment of resources, power relations and institutional co-optation. As such, the debate has to a large extent evolved into a pendulum swinging between the bashing of culture, on the one hand, and its celebration, on the other, as an explanatory factor for our understanding of Chinese business strategy. The academic debate as a whole seems hard-pressed to go beyond the divide between essentialist and anti-essentialist understandings of culture and, more fundamentally, beyond 'holistic' thinking that perceives culture - often conflated with 'a people' - as a more or less stable, coherent and internalized set of values, norms and tacit knowledge that arrays or even determines people's behaviour. As we will argue at length below, the debate is held hostage by this preoccupation with the concept of culture - anthropology's major contribution to the debate - and hence does not progress towards a more in-depth understanding of ethnic Chinese business in the region. We hold, however, that the promise of anthropology resides in matters of perspective rather than in the theoretical concept of culture itself.

The concept of culture does not just 'haunt' anthropology's engagement with the Chinese capitalism debate; it is also to be found lurking in the discipline's involvement in organization and business sciences. Anthropology has had its fair share of constructing societies or cultures as integrated wholes, as holism - the stronghold of anthropological thinking - has often been understood in terms of describing social arrangements as closed systems (Jordan 2003: 53, 87) or 'primitive isolates' - as critics of the functionalist school would say (Redfield 1955: 25). Since the 1980s however - perhaps as a reaction to the functionalist, structuralist and materialist schools whose truth-claims on the nature and form of culture were far from modest - anthropologists have largely refrained from 'macroanthropologies' on how cultural or social systems influence behaviour (Ortner 1984; Hannerz 1986). As Moore and Sanders (2006: 6) argue, ambiguity, fragmentation and conflict have become truisms in anthropology, while the idea of a structure or system - that is to say, a coherent model of social reality - is perceived as contradicting the 'countless inconsistencies and the indeterminate nature of lived life'. 
Ironically, the very moment that anthropology attempted to move away from culture as an analytic category, other disciplines started adopting it (Moore and Sanders 2006: 17). Within organization and business studies, the concept of culture has been extensively borrowed from anthropology (Smircich 1983: 339). Particularly popular has been the definition of 'organizational culture' as a system of shared symbols and meanings as developed by symbolic anthropologists (Smircich 1983). This approach addresses the problem of social order and cohesion. It therefore appealed to both organizational scholars and practitioners, since they are equally concerned with how to 'create and maintain a sense of organization, and how to achieve common interpretations of situations so that coordinated action is possible' (Smircich 1983: 351). Accordingly, the static definition of an organization as a stable system or bounded whole with fixed boundaries which 'has a culture' (Smircich 1983: 347) has dominated the early work of those scholars adopting the anthropological concept of culture (e.g. Hofstede 1991).

It is only when business anthropology emerged as a distinct perspective in the mid-1990s that the close relationship between managerial needs and analytical approach was disrupted. What may have been the 'anthropology of businesses' at first has now developed into a multidisciplinary approach, with anthropology as the lens through which businesses are viewed in terms of lifeworlds comprising everyday practices and processes of organising, sense making and meaning making 'from below' and 'from within'. Business anthropology distinguishes itself by an approach that acknowledges organizations in terms of processes of doing business and, thereby, contributes to an understanding of business culture as ambiguous and fragmented, changeable and entrenched with unequal power relations and conflicting interests (Dahles 2004).

Anthropologists have had to learn to accept fragmentation, ambiguities and vagueness as the condition of their field of study and to exploit this experience for writing more adequate studies of what happens in the organizational or business arena (see Bate 1997). In this sense, business anthropology has been a response to mainstream organization studies that oftentimes portrayed culture in an essentialist and static manner.

Considering the promise of ethnography in business and organization studies (Ybema et al. 2009; Locke 2011; Czarniawska 2012), the anthropological approach seems increasingly appreciated. This, however, leaves open the question as to what anthropology's promise is at a conceptual-theoretical level. In the remainder of this article, we argue in favour of engaging the concepts of culture and institution, and correspondingly plead for a cross-fertilization between anthropology and institutional theory within the organization and business sciences.

\section{Perspectives on Chinese Capitalism}

Inspired by Max Weber's work on Confucianism, efforts have been made 
to interpret ethnic Chinese economic accomplishments in terms of 'Confucian capitalism' or 'Chinese capitalism' (Redding 1990). Chinese capitalism has often been described in terms of a communal and informal form of capitalism in contrast with the liberal capitalism based on individual achievements that emerged in the West. Chinese capitalism is believed to be rooted in colonial times when - due to population pressure, political turmoil and poverty in China, on the one hand, and tales of burgeoning opportunities overseas, on the other - many Chinese left their homes in the coastal provinces of southern China to make a living in other parts of Southeast Asia (Kuhn 2008). This collective historical background generated discourses of the sojourner, middleman, and diasporic entrepreneur (Barrett 2012: 3-5). However divergent these discourses may be, they imply that beyond migration lie experiences of displacement, host community hostility, racial discrimination, and limited opportunities for upward mobility. Conversely, they also entail fresh prospects stemming from new economic niches and capital accumulation, by engaging in middlemen occupations and split loyalties stemming from ambivalence towards the country of residence (Kuhn 2008). In diaspora, livelihoods are easily jeopardized, so that the reliance on family and shared ethnicity for labour, capital, information and transactions may be the only viable option for minority immigrants. From this it has been argued that Chinese familism has facilitated the growth of their enterprises and the emergence of ethnic business networks - extending across the globe and providing the glue for what has come to be denoted as the transnational Chinese community (Redding 1990; Weidenbaum and Hughes 1996; Tsui-Auch 2005: 1191).

Although various studies stress the operational limits of this reliance on family and ethnic ties in business (e.g. Kiong 2005), early academic accounts have been rather celebratory of the alleged economic success of the ethnic Chinese. In addition to the idea of success, the concept of culture has played a significant role in the ways in which Chinese economic activities have been viewed by scholars. It has, however, been questioned whether many ethnic Chinese business people share bonds based on a common ethnic identity. Contesting the existence of an ethnic Chinese community based on a common culture, the institutional literature shifts focus away from community towards network-based benefits (Yeung 2000: 187-189), claiming that ethnic Chinese businessmen accumulate social capital by maintaining membership in a number of partly-overlapping networks which enables them to evade failing vertical linkages, such as uncooperative bureaucrats. This social capital based on personal trust provides the 'institutional thickness' that characterizes (ethnic) Chinese business networks in a globalizing business environment (Yeung and Olds 2000: 15-16).

In the burgeoning literature contributing to this debate, four perspectives can be discerned: the culturalist, instrumentalist, 
institutional and transnational approach to Chinese capitalism (Dahles 2010). In each of these, two questions that are at the heart of the Chinese capitalism debate are answered differently. First, "how do the ethnic Chinese in Southeast Asia do business and why in this particular way?' And second, 'what is the role of ethnicity in all this?' These two questions are highly intertwined and the analytic haze this entanglement causes forecloses a clear view of the relationship between business conduct and ethnicity. Let us now take up each of these four perspectives.

\section{The Culturalist Perspective}

A culture-based approach to Chinese capitalism arose in the fields of business studies and economics in the 1990s, when various explanations for the success of the 'Asian tiger economies' were put forward. Business gurus spoke of 'bamboo networks', 'Chinese commonwealth', and 'global tribes' to describe Chinese businesses. These businesses are supposedly rooted in a Confucian tradition and are able to develop their business ventures by operating through the family firm and guanxi networks - that is, networks built on reciprocal social relationships and informal trust. This institutional embedding has enabled them to avoid state intervention.

A similar argument has been put forward by Fukuyama in his book titled Trust, in which he argues that 'Confucian moral education' places the family above all other social ties. Fukuyama claims that in 'low-trust societies' such as the Chinese, the internalization of such ethical principles replaces state-directed law as the basis for social order (Fukuyama 1995: 56, 84). These kinship-based loyalties, moreover, supposedly accommodated the revitalization of the corridor between Southern Chinese provinces such as Fujian and Guangdong, the area from which most of the ethnic Chinese in Southeast Asia have migrated throughout the centuries, and the settlement societies of East and Southeast Asia where they now reside (ibid., p. 92).

Redding's provocatively entitled The Spirit of Chinese Capitalism sets forth a similar culturalist argument, arguing that, driven by Confucian values, overseas Chinese exhibit a distinct form of capitalism of which the most salient features include paternalism (resulting in a strong vertical order and disciplined behaviour), personalism (resulting in horizontal cooperation based on reciprocity), and insecurity within the societal environment (resulting in defensiveness and mistrust, especially towards governments) (Redding 1990: 184). It is not so much the content of such interpretations of Chinese capitalism, but rather their culturalist reading which has evoked strong criticism.

In stressing the importance of cultural factors in economic dealings, culturalist scholars agitate against economists who remove culture from their accounts (Redding 1990: 12-13). However, critics rightly point out 
that they carry the argument too far and turn to an equally simplistic culturalist side, thereby essentializing ethnic culture as if it were shared by a community, stable through time and defining social behaviour (Ooi and Koning 2007: 108). 'Chineseness' in the culturalist perspective is taken for granted as the de facto stimulus in economic conduct and, in so doing, an essentialist understanding of ethnic cultural identity is revealed. This shows affinity with Talcott Parsons' (1960) understanding of the concept of culture, and his theory of action which builds on the idea of the internalization of cultural norms, values, symbols and roles as constitutive of a person's orientation towards action. This view of culture is adopted by culturalist scholars, who thereby detach cultural values from a relational and hierarchical setting, as if the Chinese have somehow packaged a value-system back in China and proceed to deploy it wherever they reside, however many generations down the line after migration, or in whatever socio-political context. This view still bears on the academic debate about Chinese capitalism.

\section{The Instrumentalist Perspective}

Scholars applying the instrumentalist perspective are at the opposite end of the spectrum when it comes to the different approaches to Chinese capitalism. Instrumentalists play down issues of culture and stress the rationally acting economic agent as driving capitalist endeavour, arguing that Chinese do business the same way as Westerners if conditions are comparable (Chang and Tam 2004: 33). Consequently, all keycharacteristics of Chinese capitalism - that is, the importance of cultural values, family business, guanxi networking and the footloose character of Chinese enterprises - are trivialized. First, Gomez and Benton argue that culture is hardly relevant since people tend to go at it alone in the economic sphere (2004: 2). Rather than creating the misconception that the ethnic Chinese would facilitate business ties through common ethnic descent, they stress heterogeneity in Chinese business; dividing lines exist on the basis of firm size, level of assimilation into Southeast Asian societies, generations, and different relationships with the state (Gomez and Hsiao 2001: 2). Second, instrumentalist scholars oppose the notion of guanxi networking as the quintessential mode of organizing among Chinese firms (Gomez and Benton 2004: 17). Chang and Tam argue that organizational imperatives rather stem from the need to survive within market conditions, not from some mythical Chinese modus operandi based on Confucianism (2004: 28). Third, the family-centred make-up of the typical Chinese firm has a 'dark side' (Kiong 2005: 46). Personalism, paternalism, centrality of decision-making and informality commonly result in disputes and disintegration. Gomez and Hsiao (2001) show that the family loses control over the enterprise due to issues of succession and inheritance, feuds between family members leading to division, and the desire of younger generations for more transparency and 
bureaucratization. Finally, the footloose character of Chinese capitalism is questioned by observing that second and third generation migrants are rooted in their country of residence both politically and economically, and neglect ethnically based organization (Gomez and Benton 2004: 17).

Moving from business practice to ethnicity, instrumentalists imply that there is nothing Chinese about Chinese capitalism. They argue that culturalist academics and politicians alike create a false image of the ethnic Chinese as 'others' opposed to the native communities of Southeast Asia and, in so doing, amplify ethnically-based nationalist discourse. Kwok (1998: 125), for instance, states that such a 'discourse on Chineseness' is not descriptive but ascriptive, and acquires 'the status of conventional wisdom' by means of what Jamie Mackie designates the 'essentialist fallacy' (2000: 238). As a reaction to culturalist 'othering', critical scholars such as Suryadinata (1997: 5-6) claim that the ethnic Chinese of Southeast Asia are in fact Southeast Asians rather than Chinese, and that through 'Southeast Asianization' or 'acculturation' only a minority remains 'overseas Chinese'. He portrays the ex-colonial states of Southeast Asia as 'state-nations rather than nation-states' with an actual multi-ethnic character and an imagined nationality built on notions of indigenous culture which exclude immigrant minorities.

Based on a number of widely acknowledged work on ethnic identity - such as Barth's thesis on boundaries (1969), Cohen's work on the manipulation of symbols (1974), Anderson's notion of imagined communities (1983) and Eriksen's 'us' versus 'them' classifications (2002) - it is understood that "actual" ways of conduct and identifications within an ethnic category, and (re)presentations of ethnic identity do not necessarily correspond' (Koning and Verver 2012: 4). Constructivist accounts have often portrayed ethnic identities as 'manmade' political instruments and ideological constructs, rather than as culturally embedded 'entities'. Scholars have agitated against essentialized notions of ethnic identity, deconstructing them and proving ethnic identity to be unstable, contingent and context-dependent. Instrumentalist scholars take this argument to its extreme. In criticizing the essentializing tendency of the culturalist perspective, instrumentalists deconstruct the idea of an essential 'Chineseness'. The notion of ethnic identity is placed in the domain of the imaginary, whereas the actual conduct of people is claimed to have nothing to do with ethnicity. This separation of practice from discourse, however, contradicts the observation that reified presentations of ethnicity are 'sticky' and often resurface in social categorizations underlying behaviour (Koning and Verver 2012).

\section{The Institutional Perspective}

The culturalist scholars' inclination towards explaining economic conduct by referring to internalized cultural values, and the instrumentalists' 
tendency to prioritize economic rationality and label culture a farce, are brought together by institutional scholars who make use of Granovetter's notion of embeddedness. Granovetter observed that 'attempts at purposive action are instead embedded in concrete, ongoing systems of social relations' (1985: 487). This embeddedness in social relations renders both culture and capitalism dynamic, and this is the central tenet of the institutional perspective. Much in this vein, Hamilton pleads for a perspective that acknowledges that the organization of economies flows primarily from people's capitalist activities, and secondarily from the institutions framing these activities (2006: 9). People take things for granted in deciding their course of action because they participate in institutionally defined 'lived-in spheres of life', such as politics or the family (Hamilton 2006: 10). These institutional environments, however, do not determine action but rather provide resources for economic activity. As such, Hamilton views capitalism as a dynamic process characterized by competition and power struggles, as well as by continuous organizational change. Chinese business practices implying patriarchy and personalism are adaptable features, changing shape in various politico-economic settings (Hamilton 2006: 3). Adhering to a similar view, Yeung (2004) interprets 'Chinese capitalism' as a form of organization which is rooted in cultural values of Chinese society, but which has evolved and adapted in the Southeast Asian context. By analysing the impact of globalization on Chinese economic institutions, Yeung arrives at a 'hybrid capitalism that is defined by its incomplete, partial and contingent transformations' (2004: 9). Although familism and guanxi relationships remain firmly in its foundations, therefore, transformations have changed their character. Yeung describes how business networks have become international, while knowledge and experience are gained from education abroad (2004: 68). He holds that Chinese firms engage more and more with non-Chinese actors in order to acquire capital and exploit markets, transcend traditional guanxi networks, professionalize management, heighten transparency and credibility, and slacken family and paternalistic control (Yeung 2004: 4682).

In the institutionalist approach, ethnicity is treated neither as the internalization of pan-Chinese cultural values, as the culturalists claim, nor merely as a tool in the hands of the state to create a false social divide, in the way that the instrumentalists hold. Instead, ethnicity is depicted as a dynamic resource in the hands of both the state and the entrepreneur. Dahles and ter Horst $(2006,2012)$ temptingly illustrate this dynamic with respect to the Cambodian silk-weaving industry, contending that, although the industry is historically dominated by the ethnic Chinese through knowledge and networks, silk products embody a sense of Khmer authenticity. Paralleling such claims of authenticity, the silk producers are portrayed as Khmer and the silk traders as Chinese, irrespective of the observation that silk producers are often of Chinese 
descent as well. Ethnicity, then, is a resource in the socio-historical organization of the industry and in legitimizing its ethnic outlook. 'Chineseness', as a template, is institutionalized in the economic position of the middleman and wholesaler, rather than pointing towards some primordial affiliation. In any case, ethnicity should not be treated as an identity feature residing within individuals or groups, but rather as a resource at the disposal of individuals, groups, and 'others' within the social environment. The institutional perspective of Chinese capitalism thus integrates aspects of the culturalist and instrumentalist perspectives in a somewhat nuanced manner, while at the same time leaning towards the practical and socially organized, and putting less emphasis on discursive and representational dimensions. These dimensions of Chinese capitalism are fully acknowledged in the transnational perspective, as we will now see.

\section{The Transnational Perspective}

Ong and Nonini's Ungrounded Empires (1997) and Ong's Flexible Citizenship (1999) propose the notion of a footloose Chinese capitalism like that brought forward by the culturalist perspective, while simultaneously building on a combined Marxian and Foucauldian legacy (Ong 1999: 19). It is Marxist in the sense that capitalist motives are seen as 'absolutely transcendental' (Ong 1999: 7) and the driving force in shaping meaning and practice in other spheres of life (Ong 1999: 16). It is Foucauldian in the focus on subject-making through 'regimes of truth' about 'Chinese capitalism' and 'Chineseness', which are seen as objectified and reified, rather than neutral, categories (Ong 1999: 69). Ong deploys the notion of 'regime', in which she distinguishes the nation-state, marketplace and family, as different 'institutional contexts and webs of power' that try to discipline subjects through regulation and normalization of attitudes and behaviour (Ong 1999: 113). Within 'late capitalism', characterised by interconnected and rapidly transforming sites of doing business, 'diaspora Chinese' entrepreneurs flexibly accumulate wealth across borders, thereby challenging those 'regimes' that are more localized social orders. Chinese business culture, with family business and guanxi networking as its crucial characteristics, has become increasingly useful since these ties make it possible to cut across national boundaries and link business people in different places (Nonini and Ong 1997: 21). These practices, however, should not be mistaken for authentic Chinese cultural features as the culturalist scholars perceive them, but rather as discursive constructs used in the 'celebratory narratives of Chinese business success' (Nonini and Ong 1997: 21).

The theme of ethnic Chinese as operating transnationally is a common thread in the debate on Chinese capitalism. The culturalist and the transnational perspectives stress the abilities of business people to escape state disciplining (through ethnic cultural and social capital). 
Conversely, instrumentalist scholars argue that Chinese business is locally patronized. In between these extremes, institutional scholars point towards the local adaptability of an originally trans-local mode of social organization. Ong (1997: 172-173) ascribes to the ethnic Chinese a freedom of movement, and to nation-states (both in Southeast Asia and in China) a fear or rejection of such movement. However, one should be wary of celebratory accounts of the duality of the globe-trotting agent and the eroding grip of the nation-state. Transnational practices are always embedded in local power mechanisms, cultural constructions and economic relations. Ethnic expressions and acts respond to situated relationships and hierarchies; they are never free-floating but imply a degree of 'social closure' (Guarnizo and Smith 1998: 13).

In stressing flexibility, inventiveness, and the politics of identification, the transnational perspective of Chinese capitalism resonates with the instrumentalist appeal for 'deconstructing essentialisms' that trivialize the role of ethnicity in human conduct. As outlined earlier, these essentialisms take the form of objectified identity constructs. However, doing away with essentialisms misses out on understanding essentialising practices in ethnic identity politics. The transnational perspective to Chinese capitalism, showing affinity with a Foucauldian cultural studies approach, focuses on this reified 'second nature' of sociality. 'Chineseness' is not taken as a primordial entity, in the way that culturalist scholars claim, but rather as a discursive entity in which truth and power intersect. The cultural characteristics of ethnic identity (Confucianism, family values, guanxi, and so on), then, are treated as 'discursive tropes' that are used in both the state's nationalist agenda and by Chinese entrepreneurs to negotiate a path towards economic success and social well-being (Nonini and Ong 1997: 9).

The major pitfall of this view of ethnicity as a postmodern grab bag of cultural characteristics is that it overemphasizes agency in selfpresentation while neglecting the critical role of social 'others'. As Yao cautions (2009: 255), identification is 'also about collective demands, cultural obligations and communal acceptance'. This is especially relevant in Southeast Asia where ethnic relations and state policies attached to them have been tense from time to time. Ethnic culture freed from racial connotation - such as the idea that 'a black American or a white New York Jew can become Chinese by eating 'Chinese food" (Yao 2009: 259) - is a utopia that the transnationalist perspective to Chinese capitalism fails to acknowledge. Culture and race are always conflated in notions of ethnic identity. Therefore one may claim that Ong and Nonini reinforce an essentialist understanding of ethnicity, albeit in a discursive, rather than primordial, way. Nevertheless, the transnationalist perspective to Chinese capitalism does convincingly argue that one should not merely look at how ethnic culture and identification shape social action (as is overdone by the culturalists and rejected by the instrumentalists), but also at how representations of ethnic culture and identity are used to give meaning to 
and legitimize actions and viewpoints. A summary of the diverse viewpoints is presented in Table 1 below.

Table 1: Perspectives of Chinese capitalism.

\begin{tabular}{|c|c|c|c|c|}
\hline \multirow{2}{*}{$\begin{array}{l}\text { Chinese } \\
\text { capitalism }\end{array}$} & \multicolumn{4}{|c|}{ Perspectives } \\
\hline & Culturalist & Instrumentalist & Institutional & Transnational \\
\hline $\begin{array}{l}\text { Business } \\
\text { culture }\end{array}$ & $\begin{array}{l}\text { Determines } \\
\text { economic } \\
\text { behaviour }\end{array}$ & $\begin{array}{l}\text { Minor role in } \\
\text { economic } \\
\text { behaviour }\end{array}$ & $\begin{array}{l}\text { Dynamic } \\
\text { interplay } \\
\text { between } \\
\text { cultural } \\
\text { institutions } \\
\text { and capitalist } \\
\text { opportunities }\end{array}$ & $\begin{array}{l}\text { Discursively } \\
\text { deployed in } \\
\text { economic } \\
\text { endeavour }\end{array}$ \\
\hline $\begin{array}{l}\text { Business- } \\
\text { nation-state } \\
\text { relationship }\end{array}$ & $\begin{array}{l}\text { Culture } \\
\text { ignores the } \\
\text { nation- } \\
\text { state }\end{array}$ & $\begin{array}{l}\text { Nation-state } \\
\text { controls } \\
\text { business }\end{array}$ & $\begin{array}{l}\text { Cultural } \\
\text { institutions } \\
\text { embedded in } \\
\text { local power- } \\
\text { structures }\end{array}$ & $\begin{array}{l}\text { Capitalist } \\
\text { behaviour } \\
\text { escapes state } \\
\text { control }\end{array}$ \\
\hline $\begin{array}{l}\text { Market } \\
\text { opportunities }\end{array}$ & $\begin{array}{l}\text { Hardly } \\
\text { mentioned }\end{array}$ & $\begin{array}{l}\text { Determining } \\
\text { economic } \\
\text { behaviour }\end{array}$ & $\begin{array}{l}\text { Reshaping } \\
\text { cultural } \\
\text { institutions }\end{array}$ & $\begin{array}{l}\text { Inspiring } \\
\text { discursive } \\
\text { deployment } \\
\text { of culture }\end{array}$ \\
\hline Ethnicity & $\begin{array}{l}\text { Ethnic } \\
\text { cultural } \\
\text { identity } \\
\text { and } \\
\text { practice as } \\
\text { lasting and } \\
\text { coherent }\end{array}$ & $\begin{array}{l}\text { Culture being } \\
\text { irrelevant }\end{array}$ & $\begin{array}{l}\text { Ethnic } \\
\text { culture as a } \\
\text { dynamic } \\
\text { resource in } \\
\text { the interplay } \\
\text { with social } \\
\text { organization }\end{array}$ & $\begin{array}{l}\text { Ethnic } \\
\text { culture and } \\
\text { identity as } \\
\text { 'politics' to } \\
\text { negotiate } \\
\text { capitalist } \\
\text { behaviour }\end{array}$ \\
\hline
\end{tabular}

\section{Towards a Liaison Amoureuse between Business Anthropology and Institutional Theory}

The Chinese capitalism debate is caught in a dichotomy of constructivist versus essentialist approaches to culture, moving in circles from primordial essentialism (culturalist perspective), to deconstructing essentialism (instrumentalist perspective), and back to essentialism through a discursive detour (transnational perspective). Not unlike how Brubaker and Cooper argue for the concept of identity (2000: 10-11), culture as an analytic category runs the risk of meaning either too much, in the sense of a bounded and stable set of characteristics that 'resides' within an ethnic group, or too little, when seen as fluid, multiple, 
manipulated, etcetera. Relatedly, the pendulum swinging between essentialism and anti-essentialism forces a false choice between 'an acultural analysis of power and an apolitical analysis of culture' (Friedland and Alford 1991: 254). In other words, culture is either presented as straightforwardly determining business practices without much regard for individual agency (culturalist perspective), or as only manipulated by agents in order to secure power and interests (instrumentalist and transnational perspectives). There is no progress towards an understanding of culture as dynamic and constantly changing; instead it is viewed as either explanans or explanandum. A truly dynamic conceptualization would acknowledge that culture sometimes arrays behaviour and is sometimes manipulated, that culture changes throughout time and space, and that culture stands in interrelation to other dimensions in business organizations. We believe that reconceptualising Chinese capitalism as an institution - or better, as subject to processes of institutionalization - opens up this possibility of dynamism, and avoids versions of 'holism' and essentialism that cling to the concept of culture to rebound time and again.

An institution, as a starting point, may broadly be defined as an informal or formalized organizing principle that is shared by a collective and is enacted through both action and thought (cf. Durão and Lopes 2011: 363). Institutional templates manifest within a broader social setting - organizational field or society - and over time acquire a takenfor-granted status that arrays and disciplines the behaviour of organizational actors (Greenwood et al. 2008). Apart from avoiding the burdensome legacy of the concept of culture within the Chinese capitalism debate, the concept of institution has the advantage of incorporating cultural, social and material dimensions of business organization within a single framework. Scott (2008: 48), for example, notes that institutions are 'made up of symbolic elements, social activities and material resources'. Culture, then, is a resource in processes of institutionalization which stands in a dynamic interrelationship with social and material dimensions - sometimes converging and reinforcing each other, sometimes conflicting with each other. This interrelationship appears through analysing the 'organizational framing of business-related activities', as do 'larger structures of power, as well as the limits and opportunities of individual agency' (Moeran and Garsten 2012: 13).

Both anthropology and organizational institutionalism have been internally divided over the ontological status of culture. Within institutional theory the definition of culture - as one of the pillars in processes of institutionalization - has shifted. Whereas culture was long interpreted as a more or less coherent system of norms and values that human actors internalize, within what has been labelled the 'new institutionalism', culture came to be seen as a cognitive phenomenon that revolves around the production of scripts, rules, classifications and legitimizations (Powell and DiMaggio 1991). Scholars came to explore 
culture as external semiotic frameworks and shared knowledge, as opposed to internalized beliefs as in the 'old institutionalism'. In anthropology, a comparable yet different shift has occurred in the ontology of culture. Since postmodernism and poststructuralism took root in the 1980s and 90s, scholars moved from delineating 'a culture' as 'a people' to understanding it as 'a political process of contestation over the power to define key concepts, including that of 'culture' itself' (Wright 1998: 14), rather than as a bounded and fixed 'thing'. However, whereas organizational institutionalism remained a study of cultural systems inferring the existence of culture from macro-organizational patterns the shift from culture as internalized beliefs to external frameworks in anthropology implied a shift to agency as well. Roughly, anthropology shifted focus from how culture 'produces' behaviour to how people's behaviour 'produces' culture (Moore and Sanders 2006: 17). Currently, in as much as institutional scholars hardly acknowledge the 'politics of culture', anthropologists have somewhat overblown the postmodernist argument. Taken together, however, culture can be perceived as a resource in processes of institutionalization that are dynamic rather than fixed precisely because culture both arrays social behaviour and yet can be negotiated and manipulated in interaction.

Dynamism is a crucial notion in processes of institutionalization, which manifests itself in the relationship between cultural and social dimensions, but also in the dialectic between agency and structure, and in bridging micro and macro levels of sociality (Mohr and White 2008). Thus, framing 'Chinese capitalism' as an institution must not be taken as an attempt to make truth-claims about a supposedly fixed nature and form of how those Southeast Asians with Chinese roots organize business life - this would be little more than essentialism in another disguise. Whereas the analytic focus should be on institutionalization rather than 'the institution' as such, the notion of Chinese capitalism is useful as a 'heuristic device' (Yeung 2004: 1) or, alternatively, as a 'conceptmetaphor' that aims to maintain rather than resolve ambiguity by preserving 'a tension between pretentious universal claims and particular contexts and specifics' (Moore 2004: 74). Anthropology is well-positioned to assure this sense of ambiguity and specificity.

We believe that the merits of integrating anthropological and institutional approaches extend beyond the debate about Chinese capitalism in Southeast Asia, and beyond conceptualizing culture. Within the organization and business sciences - despite obvious parallels in perspective and interests - anthropology and institutionalism have hardly engaged in cross-fertilization. However, as much as the concept of institutionalization may advance the anthropology of business organization, so might an anthropological approach deal with some persistent lacunas which exist within organizational institutionalism, and which have been pinpointed by leading scholars in the field. Institutionalists largely adhere to a quantitative methodology which, 
firstly, makes it hard to grasp meaning:

It is much easier to count structures and organizational forms than it is to measure meaning systems. ... if we are to take seriously the ideational aspects of institutions, we need to move, however slightly, away from strictly positivist research and incorporate interpretivist methods that pay serious attention to the subjective ways in which actors experience institutions.'

(Suddaby 2010: 16).

Second, although institutionalists do acknowledge that institutions and actions are interlinked and that institutionalization is a dynamic process, they have in fact had persistent difficulty in capturing agency and, relatedly, the processual and 'everyday' character of organizational behaviour (Powell and Colyvas 2008: 277). This is largely due to the tendency of institutionalists to focus on the macro-structural outcomes rather than the actual process of institutionalization (Zilber 2002: 235), as so omitting the relative power and interests of actors in the politics of maintaining order (Clegg 2010). An anthropological perspective would certainly contribute to understanding institutionalization by emphasizing the situated practices and meaning-making by individual agents, without which any broader social order is by definition inexistent. As such, Zilber - one of the few organizational institutionalists who explicitly deploys an ethnographic methodology - comes to the conclusion that 'it is the continuous enactment of practices and meanings by organization members that constitutes and maintains institutions' (2002: 251).

\section{Conclusions}

To end on a positive note, scholars in the field of institutional analysis have recently answered the plea for an integrated perspective in organizational studies with regard to another one of anthropology's hallmarks - the importance of historical context. The concept of 'legacies of the past' has been applied in order to address societal transformations as a function of the social, cultural, and institutional structures created under past regimes that persist in the present period. Proponents of this approach argue that dominant social, cultural, and political forces at work in the larger society are rooted in power struggles that evolved throughout history and currently shape the identity of new institutions. Turning to the field of international organizational and business studies, we believe that the concept of legacies helps capture the role of businesses, not in terms of passive recipients of institutional resources 'but as actors involved in both the construction and reconstruction of such resources within and across national contexts' (Morgan and Quack 2005: 1765). It is in this context that the analysis of 'institutional legacies' has been proposed. As firms internationalize they have to deal with increasing diversity in both their organizational practice and institutional 
environment and may draw 'on 'sleeping' nearly forgotten institutional legacies as a resource for their institutional change projects' (Morgan and Quack 2005).

A comparative perspective on Chinese capitalism in Southeast Asia reveals the ways in which both long-standing and newly created institutional legacies are strategically employed, abandoned, even silenced, before being revitalized in cross-border ventures under rapidly changing and ambivalent institutional regimes. In the final analysis, the concept of Chinese in Southeast Asia is not rooted in a homogeneous and static 'community' with 'a culture', but one which comprises multiple loyalties and at the same time is rapidly being transformed into a loosely connected patchwork of partly diverging, but nevertheless interrelated and internally heterogeneous, sub-communities. It is clear that community is identified, not as a shared ethnic culture, but in the situational and contextual terms of a common, though diverse, history that comprehends ancestral roots in China and a shared migratory past, as much as it is identified as a shared colonial experience that generated diverging legacies for the post-colonial nation states to build on (Dahles 2010; Dahles and Koning 2013). This aspect has not been acknowledged by current institutional theorists, who position Chinese capitalism in overlapping networks rooted in economic, social, and political relations. One dimension to be included in this framework - giving it historical depth - is the embeddedness in institutional legacies. This embeddedness may be strategically employed, abandoned, even silenced and again revitalized under rapidly changing conditions in the global economy. It is in a liaison amoureuse between institutional theory and business anthropology that the anthropology of Chinese capitalism comes to fruition.

\section{References}

Anderson, B. 1983 Imagined Communities: Reflections on the Origin and Spread of Nationalism. London, New York: Verso.

Barrett, T. C. 2012 The Chinese Diaspora in Southeast Asia: The Overseas Chinese in Indochina. London, New York: I.B. Tauris.

Barth, F. (ed.) 1969 Ethnic Groups and Boundaries: The Social Organization of Culture Difference. Boston: Little, Brown and Company.

Bate, S. P. 1997 'Whatever happened to organizational anthropology? A review of the field of organizational ethnography and anthropological studies.' Human Relations 50 (9): 1147-1175.

Brubaker, R. and F. Cooper 2000 'Beyond "identity".' Theory and Society 29: 1-47.

Chang, L.-Y. and T. Tam 2004 'The making of Chinese business culture: culture versus organizational imperatives,' pp. 23-38 in E. T. Gomez and 
H.-H. M. Hsiao (eds.) Chinese Enterprise, Transnationalism and Identity. New York: Routledge.

Clegg, S. 2010 'The State, Power, and Agency: Missing in Action in Institutional Theory.' Journal of Management Inquiry 19 (1): 4-13 .

Cohen, A. 1974 Two-Dimensional Man: An Essay on the Anthropology of Power and Symbolism in Complex Society. London: Routledge and Kegan Paul.

Czarniawska, B. 2012 'Organization theory meets anthropology: a story of an encounter.' Journal of Business Anthropology 1 (1): 118-140.

Dahles, H. 2004 'McBusiness versus Confucius? Anthropological perspectives on transnational organizations and networks.' Inaugural Lecture. Amsterdam: VU University.

Dahles, H. 2010 'The multiple layers of a transnational "imagined community": the notion and reality of the ethnic Chinese business community,' pp. 55-81 in M.-L. Djelic and S. Quack (eds.) Transnational Communities Shaping Global Economic Governance. Cambridge: Cambridge University Press.

Dahles, H. and J. ter Horst 2006 'Weaving into Cambodia: negotiated ethnicity in the (post)colonial silk industry,' pp. 119-132 in L. C-P. Ollier and T. Winter (eds.) Expressions of Cambodia: The Politics of Tradition, Identity, and Change. London: Routledge

Dahles, H. and J. ter Horst 2012 'Institutionalising Chineseness. The legacies of Chinese commercial hegemony in the Cambodian silk industry.' Journal of Contemporary Asia 42(2): 210-229.

Dahles, H. and J. Koning 2013 'Chinese business ventures into China: multilayered legacies of Southeast Asian Chinese communities,' pp. 418437 in D. Caulkins and A.T. Jordan (eds.) Companion to Organizational Anthropology. Oxford: Wiley/Blackwell.

Durão, S. and D. S. Lopes 2011 'Introduction: institutions are us?' Social Anthropology / Anthropologie Sociale 19(4): 363-377.

Eriksen, T. H. 2002 Ethnicity and Nationalism. London: Pluto Press (2nd edition).

Friedland, R. and R. R. Alford 1991 'Bringing society back in: symbols, practices, and institutional contradictions,' pp. 232-263 in W. W. Powell and P. J. DiMaggio (eds.) The New Institutionalism in Organizational Analysis. Chicago and London: University of Chicago Press.

Fukuyama, F. 1995 Trust: The Social Virtues and the Creation of Prosperity. New York: Free Press.

Glassman, J. 2005 'On the borders of Southeast Asia: cold war geography and the construction of the other.' Political Geography 24: 784-807.

Gomez, E. T. and H.-H. M. Hsiao 2001 'Introduction: Chinese business 
research in Southeast Asia,' pp. 1-37 in E. T. Gomez and H.-H. M. Hsiao (eds.) Chinese Business in Southeast Asia: Contesting cultural explanations, researching entrepreneurship. Richmond: Curzon Press.

Gomez, E. T. and G. Benton 2004 'Introduction: de-essentializing capitalism: Chinese enterprise, transnationalism, and identity,' pp. 1-33 in E.T. Gomez and H.-H. M. Hsiao (eds.) Chinese enterprise, Transnationalism, and Identity. London and New York: RoutledgeCurzon.

Granovetter, M. 1985 'Economic action and social structure: the problem of embeddedness.' American Journal of Sociology 91 (3): 481- 510.

Greenwood, R., Oliver, C., Sahlin, K., and R. Suddaby (eds.) 2008 The Sage Handbook of Organizational Institutionalism. Los Angeles and London: Sage.

Guarnizo, L. E. and M. P. Smith 1998 'The locations of transnationalism,' pp. 3-34 in M. P. Smith and L. E. Guarnizo (eds.) Transnationalism From Below. New Brunswick and London: Transaction Publishers.

Halib, M. and T. Huxley 1996 'Introduction,' pp. 1-10 in M. Halib and T. Huxley (eds) An Introduction to Southeast Asian Studies. London: I.B. Tauris \& Co.

Hamilton, G. C. 2006 Commerce and Capitalism in Chinese Societies. London and New York: Routledge.

Hannerz, U. 1986 'Theory in anthropology: small is beautiful? The problem of complex cultures.' Comparative Studies in Society and History 28 (2): 362-367.

Hill, L. And M. Hitchcock 1996 'Anthropology,' pp. 11-45 in M. Halib and T. Huxley (eds) An Introduction to Southeast Asian Studies. London: I.B. Tauris.

Hofstede, G. 1991 Cultures and Organizations: Software of the Mind. London: McGraw-Hill.

Jordan, A. T. 2003 Business Anthropology. Long Grove, IL: Waveland Press.

King, V. T. and W. D. Wilder 2003 The Modern Anthropology of Southeast Asia. London and New York: Routledge-Curzon.

Kiong, T. C. 2005 'Feuds and legacies: conflict and inheritance in Chinese family businesses.' International Sociology 20 (1): 45- 70.

Koning, J. and M. Verver 2012 'Historicizing the 'ethnic' in ethnic entrepreneurship: the case of the Chinese in Bangkok.' Entrepreneurship \& Regional Development: An International Journal. Online First, DOI: 10.1080/08985626.2012.729090.

Kuhn, P. A. 2008 Chinese Among Others: Emigration in Modern Times. Singapore: National University of Singapore Press. 
Kwok, K. W. 1998 'Being Chinese in the modern world,' pp. 121-125 in L. Pan (ed.) The Encyclopedia of the Chinese Overseas. Singapore: Archipelago Press.

Locke, K. 2011 'Field research practice in management and organization studies: reclaiming its tradition of discovery.' Academy of Management Annals 5 (1): 613-652.

Mackie, J. 2000 'The economic roles of the Southeast Asian Chinese: information gaps and research needs,' pp. 234-260 in Chan K. B. (ed.) Chinese Business Networks: State, Economy and Culture. Singapore: Prentice Hall.

Moeran, B. and C. Garsten 2012 'What's in a name? Editors' Introduction to the Journal of Business Anthropology.' Journal of Business Anthropology 1 (1): 1-19.

Mohr, J. and H. White 2008 'How to model an institution.' Theory and Society 37 (5): 485-512.

Moore, H. L. 2004 'Global anxieties: concept-metaphors and pretheoretical commitments in anthropology.' Anthropological Theory 4 (1): 71-88.

Moore, H. L. and T. Sanders 2006 'Anthropology and epistemology,' pp. 121 in H.L. Moore and T. Sanders (eds.) Anthropology in Theory: Issues in Epistemology. Oxford: Blackwell.

Morgan, G. and S. Quack 2005 'Institutional legacies and firm dynamics: the growth and internationalization of British and German law firms.' Organization Studies 26 (12): 1765-1786.

Nonini, D. M. and A. Ong 1997 'Introduction: Chinese transnationalism as an alternative modernity,' pp. 3-35 in A. Ong and D. M. Nonini (eds.)

Ungrounded Empires: The Cultural Logics of Modern Chinese Transnationalism. New York and London: Routledge,.

Ooi, C.-S. and J. Koning 2007 'Introduction: the business of identity.' East Asia 24 (2): 107- 110.

Ong, A. 1997 'Chinese modernities: narratives of nation and of capitalism,' pp. 171-202 in A. Ong and D. M. Nonini (eds.) Ungrounded Empires: The Cultural Logics of Modern Chinese Transnationalism. New York and London: Routledge,

Ong, A. 1999 Flexible Citizenship: The Cultural Logics of Transnationality. Durham: Duke University Press.

Ong, A. and D. Nonini (eds.) 1997 Ungrounded Empires: The Cultural Politics of Modern Chinese Transnationalism. London and New York: Routledge.

Ortner, S. B. 1984 'Theory in anthropology since the sixties.' Comparative Studies in Society and History 26 (1): 126-166. 
Parsons, T. 1960 'A sociological approach to the study of organizations,' pp. 16-96 in T. Parsons (ed.) Structure and Process in Modern Societies. Glencoe: Free Press.

Powell, W. W. and J. A. Colyvas 2008 'Microfoundations of institutional theory,' pp. 276-298 in R. Greenwood, C. Oliver, K. Sahlin and R. Suddaby (eds.) The Sage Handbook of Organizational Institutionalism. Los Angeles and London: Sage.

Powell, W. W. and P. J. DiMaggio (eds.) 1991 The New Institutionalism in Organizational Analysis. Chicago and London: University of Chicago Press. Redding, S. G. 1990 The Spirit of Chinese Capitalism. New York: Walter de Gruyter.

Redfield, R. 1955 The Little Community: Viewpoints for the Study of a Human Whole. Chicago: University of Chicago Press.

Scott, W. R. 2008 Institutions and Organizations: Ideas and Interests. Los Angeles and London: Sage.

Smircich, L. 1983 'Concepts of Culture and Organizational Analysis.' Administrative Science Quarterly 28 (3): 339-358.

Suddaby, R. 2010 'Challenges for institutional theory.' Journal of Management Inquiry 19 (1): 14-20.

Suryadinata, L. 1997 'Ethnic Chinese in Southeast Asia: overseas Chinese, Chinese overseas or Southeast Asians?,' pp.1-24 in L. Suryadinata (ed.) Ethnic Chinese as Southeast Asians. Singapore: Institute of Southeast Asian Studies.

Tsui-Auch, L. S. 2005 'Unpacking regional ethnicity and the strength of ties in shaping ethnic entrepreneurship.' Organizational Studies 26 (8): 1189-1216.

Weidenbaum, M. and S. Hughes 1996 The Bamboo Network: How Expatriate Chinese Entrepreneurs Are Creating a New Economic Superpower in Asia. New York: The Free Press.

Wright, S. 1998 'The politicization of "culture”.' Anthropology Today 14 (1): 7-15.

Yao S. 2009 'Being essentially Chinese.' Asian Ethnicity 10 (3): 251-262.

Ybema, S., Yanow, D., Wels, H., and F. Kamsteeg (eds.) 2009 Organizational Ethnography: Studying the Complexities of Everyday Life. Los Angeles and London: Sage.

Yeung, H. W. C. 2000 'State intervention and neoliberalism in the globalizing world economy: lessons from Singapore's regionalization programme.' The Pacific Review 13 (1): 133-162.

Yeung, H. W. C. 2004 Chinese Capitalism in a Global Era: Towards a Hybrid Capitalism. London and New York: Routledge. 
Yeung, H. W. C. and K. Olds 2000. 'Globalizing Chinese business firms: where are they coming from, where are they heading?,' pp. 1-30 in H. W. C. Yeung and K. Olds (eds.) Globalization of Chinese Business Firms. Houndmills, Basingstoke: Macmillan Press.

Zilber, T. B. 2002 'Institutionalization as an interplay between actions, meanings, and actors: the case of a rape crisis center in Israel.' Academy of Management Journal 45 (1): 234-254.

Michiel Verver is a $\mathrm{PhD}$ candidate in the Department of Organization Sciences of VU University Amsterdam (the Netherlands). His research interests include entrepreneurship, family business and state-business relationships among the ethnic Chinese in Southeast Asia (and in Cambodia in particular). He has published in Cross-Currents: East Asian History and Culture Review and in Entrepreneurship \& Regional Development: An International Journal (co-authored with Juliette Koning). He may be reached at M.J.Verver@vu.nl

Heidi Dahles is Professor in International Business \& Asian Studies at Griffith Business School, Griffith University, Brisbane (Australia). Her research interest is in the ethnic and cultural dimensions of Asian business and the intricacies of cross-border business ventures. She has published in numerous peer-reviewed journals. Among her recent books are Capital and Knowledge: Changing Power Relations in Asia (co-edited with Otto van den Muijzenberg, 2003) and Multicultural Organizations in Asia (co-edited with Loh Wei Leng, 2006). Heidi is Reviews Editor for the Journal of Business Anthropology and Editor-in-Chief (with Ooi Can Seng and Juliette Koning) of the Open Access journal Asia Matters: Business, Culture and Theory. She may be reached at h.dahles@griffith.edu.au 